\title{
Uji In-Vitro Kemampuan Ekstrak Metanol Bunga dan Daun Tanaman Kembang Telang (Clitoria ternatea L.) dalam Menghambat Pertumbuhan Jamur Fusarium oxysporum f.sp. cepae
}

\author{
Tarkus Suganda ${ }^{1}$, Indah NC Simarmata ${ }^{2}$, Yadi Supriyadi ${ }^{1}$, dan Endah Yulia ${ }^{1}$ \\ ${ }^{1}$ Departemen Hama dan Penyakit Tumbuhan, Fakultas Pertanian, Universitas Padjadjaran \\ ${ }^{2}$ Program Studi Agroteknologi, Fakultas Pertanian, Universitas Padjadjaran \\ *Alamat korespondensi: tarkus.suganda@unpad.ac.id
}

\begin{abstract}
In-Vitro Effectiveness Test of Methanol Extract of Butterfly Pea (Clitoria ternatea L.) Flower and Leaf in Inhibiting the Growth of Fusarium oxysporum f.sp. cepae
\end{abstract}

Fusarium basal rot disease (Fusarium oxysporum f.sp. cepae- Foc) is one of the main problems in the cultivation of shallots. Foc is a soil-borne pathogen that is difficult to control using synthetic fungicides because it can leave residues that are harmful to the environment, human health and can disturb the balance of the ecosystem. Plant-based fungicide is another alternative that can be developed. Butterfly pea is one of the potential plants to be used because it contains antimicrobial compounds. The aim of this study was to examine the effectiveness of butterfly pea flower and leaf methanol extracts to suppress the in-vitro growth of Foc. The experiments were arranged in a Completely Randomized Design (CRD) by testing the flower and leaf methanol extract on colony growth, conidial production and conidial germination. The result showed that the flower methanol extract gave the highest suppression on colony growth at the concentration of $1.8 \%$ (35.11\%), while the leaf methanol extract was at the concentration of $2.4 \%(47.11 \%)$. All concentrations of both methanol extracts of butterfly pea tested were able to suppress the conidial production of Foc. There was no treatment of butterfly pea methanol extract both flowers and leaf which could inhibit the conidial germination of Foc.

Keywords: Botanical pesticide, Fusarium basal rot, Shallot

\begin{abstract}
ABSTRAK
Penyakit moler (Fusarium oxysporum f.sp. cepae, Foc) merupakan salah satu kendala utama dalam budidaya tanaman bawang merah. Jamur Foc merupakan patogen tular tanah sehingga sulit untuk dikendalikan. Pengendalian menggunakan fungisida sintetik pada tanah tidak dianjurkan untuk dilakukan karena dapat meninggalkan residu yang berbahaya bagi lingkungan dan kesehatan manusia serta dapat mengganggu keseimbangan ekosistem. Salah satu alternatif pengendalian yang dapat dikembangkan adalah penggunaan fungisida nabati. Kembang telang merupakan tanaman potensial untuk digunakan karena memiliki kandungan senyawa antimikroba. Penelitian ini bertujuan untuk menguji kemampuan ekstrak metanol bunga dan daun tanaman kembang telang dalam menekan pertumbuhan Foc secara in vitro. Percobaan disusun dalam Rancangan Acak Lengkap (RAL) dengan pengujian ekstrak metanol bunga dan daun terhadap pertumbuhan koloni, produksi konidia dan perkecambahan konidia jamur. Hasil percobaan menunjukkan bahwa ekstrak metanol bunga memberikan penekanan tertinggi pada konsentrasi $1,8 \%(35,11 \%)$, sedangkan ekstrak metanol daun pada konsentrasi 2,4\% (47,11\%). Semua konsentrasi ekstrak metanol bunga dan daun tanaman kembang telang menekan produksi konidia jamur Foc. Tidak ada perlakuan ekstrak metanol, baik bunga maupun daun yang dapat menghambat perkecambahan konidia jamur Foc.
\end{abstract}

Kata kunci: Pestisida nabati, Penyakit moler, Bawang merah 


\section{PENDAHULUAN}

Bawang merah (Allium cepa L. var. agregatum) merupakan salah satu komoditas hortikultura utama di Indonesia dan termasuk dalam kelompok tanaman rempah. Bawang merah digunakan sebagai bumbu penyedap makanan dan sebagai bahan obat tradisional. Bawang merah menjadi salah satu komoditas yang menjadi sumber ekonomi dan kesempatan kerja bagi masyarakat serta memberikan kontribusi untuk perkembangan ekonomi wilayah (Litbang Pertanian, 2007).

Produksi bawang merah nasional masih menghadapi berbagai tantangan sehingga produksinya mengalami penurunan. Menurut data BPS (2019) produksi bawang merah pada tahun 2017 dilaporkan mencapai 1.503.438 ton dan pada tahun 2018 mengalami penurunan menjadi 1.470 .155 ton. Fusarium oxysporum f.sp. cepae (Foc) merupakan salah satu patogen penting yang menjadi faktor pembatas produktivitas bawang merah (Dinakaran et al., 2004). Jamur Foc dapat menyebabkan kehilangan hasil sampai 50\% (McDonald et al., 2004). Pengendalian Foc oleh petani biasanya dengan penggunaan fungisida sintetik berbahan aktif mankozeb, propineb, klorotalonil, mandipropamid, dan lain-lain (Susanti, 2018).

Penggunaan fungisida sintetik secara terusmenerus akan meninggalkan residu terhadap lingkungan dan berbahaya bagi kesehatan manusia (Agrios, 2005; Chethana et al., 2012). Oleh karena itu dibutuhkan alternatif pengendalian lain yang lebih ramah lingkungan. Pestisida nabati merupakan pestisida yang berasal dari tumbuhan dengan sifat mudah terdegradasi di alam (bio-degradable) sehingga dapat dimanfaatkan untuk mengendalikan penyakit tumbuhan karena tidak menimbulkan residu yang signifikan pada tanaman maupun pada lingkungan (Litbang Pertanian, 2012).

Tanaman kembang telang (Clitoria ternatea L.) dilaporkan memiliki sifat anti mikroba (Darsini \& Shamsad, 2013; Kamilla et al., 2009; Naz et al., 2013). Ekstrak metanol daun kembang telang menunjukkan penghambatan terhadap hifa jamur $A$. niger dengan IC $\mathrm{C}_{50} 0,4 \mathrm{mg} / \mathrm{ml}$ (Kamilla et al., 2009). Suganda \& Adhi (2017) melaporkan bahwa ekstrak air bunga kembang telang pada konsentrasi 5\% mampu menghambat pertumbuhan Foc mencapai 46\%. Das et al. (2014) melaporkan bahwa ekstrak daun etanol $(50 \%)$ dari kembang telang memiliki aktivitas antijamur dan dapat digunakan untuk melindungi benih kacang kapri dari infeksi $F$. oxysporum.
Berdasarkan laporan hasil penelitian tersebut diketahui bahwa ekstrak tanaman Kembang Telang dapat dimanfaatkan sebagai pestisida nabati untuk mengendalikan jamur patogen, namun kemampuannya dalam menghambat pertumbuhan koloni jamur Foc secara in-vitro belum diketahui. Penelitian ini bertujuan untuk menguji kemampuan ekstrak metanol bunga maupun daun Kembang Telang dalam menghambat pertumbuhan koloni, produksi konidia, dan perkecambahan konidia jamur Foc.

\section{BAHAN DAN METODE}

Percobaan dilaksanakan di Laboratorium Fitopatologi Departemen Hama dan Penyakit Tumbuhan Fakultas Pertanian Universitas Padjadjaran, Kecamatan Jatinangor, Kabupaten Sumedang, Provinsi Jawa Barat dari bulan April sampai Juni 2019. Percobaan menggunakan metode eksperimental dengan Rancangan Acak Lengkap (RAL) yang terdiri atas 4 perlakuan dengan 7 ulangan.

Perlakuan yang digunakan dalam percobaan ekstrak metanol bunga kembang telang terhadap Foc adalah sebagai berikut:

A = Kontrol (tanpa perlakuan ekstrak) + Foc

$\mathrm{B}=$ Ekstrak metanol bunga $0,6 \%+$ Foc

$\mathrm{C}=$ Ekstrak metanol bunga 1,2\% + Foc

$\mathrm{D}=$ Ekstrak metanol bunga 1,8\% + Foc

Perlakuan yang digunakan dalam percobaan ekstrak metanol daun kembang telang terhadap Foc adalah sebagai berikut:

A = Kontrol (tanpa perlakuan ekstrak) + Foc

$\mathrm{B}=$ Ekstrak metanol daun 0,8\% + Foc

$\mathrm{C}=$ Ekstrak metanol daun 1,6\% + Foc

$\mathrm{D}=$ Ekstrak metanol daun 2,4\% + Foc

Semua ekstrak dibuat dalam volume/volume. Isolat Foc yang digunakan diisolasi dari tanaman bawang terinfeksi penyakit moler di pertanaman bawang daerah Brebes tahun 2018.

\section{Pembuatan Ekstrak Metanol Bunga dan Daun Kembang Telang}

Bunga dan daun kembang telang yang telah berkembang sempurna (dewasa) diambil secara komposit dari tanaman kembang telang di Kebun Percobaan Ciparanje, Fakultas Pertanian Universitas Padjadjaran di Jatinangor, Sumedang, Jawa Barat. Pembuatan ekstrak dilakukan dengan menggunakan metode maserisasi (Dono dkk., 2008). Daun dicuci bersih terlebih dahulu sebelum dikering-anginkan, sedangkan pada bunga tidak dilakukan pencucian 
karena lebih mudah hancur dan rusak saat terkena air. Bunga dan daun kemudian dikering-anginkan sambil dibolak balik secara berkala selama kurang lebih satu minggu. Bunga dan daun yang telah kering kemudian dihaluskan menjadi serbuk halus (simplisia) menggunakan blender.

Simplisia masing-masing daun dan bunga kembang telang sebanyak $200 \quad \mathrm{~g}$ dimaserasi/direndam dalam pelarut metanol sebanyak $2000 \mathrm{ml}$. Rendaman dibiarkan selama tiga hari di dalam wadah tertutup. Filtrat dan ampas dipisahkan dengan penyaringan menggunakan kertas saring. Filtrat dikumpulkan dan dievaporasi menggunakan rotary evaporator pada suhu $55-60^{\circ} \mathrm{C}$ dan tekanan 580-600 mmHg. Hasil akhir ekstrak kembang telang berupa pasta dan disimpan di dalam lemari pendingin dengan suhu $\pm 5^{\circ} \mathrm{C}$ untuk menjaga kualitasnya.

\section{Uji Daya Hambat terhadap Pertumbuhan Koloni secara In-vitro}

Uji penghambatan ekstrak metanol bunga kembang telang terhadap patogen yang diuji dilakukan dengan menggunakan metode umpan beracun (food poisoning) seperti yang dilakukan oleh Kurniasih dkk. (2014). Pengujian dilakukan dengan menumbuhkan jamur patogen yang diuji dalam media PDA yang telah dicampur dengan ekstrak tanaman kembang telang. Masing-masing ekstrak metanol bunga dan daun kembang telang ditimbang sesuai konsentrasi perlakuan lalu dilarutkan dalam $5 \mathrm{ml}$ akuades steril dan dicampurkan secara perlahan-lahan dengan PDA cair dengan suhu $\pm 50^{\circ} \mathrm{C}$. PDA dan ekstrak diaduk menggunakan batang pengaduk agar campuran merata. Setelah rata, campuran media lalu dituang sebanyak lebih kurang $10 \mathrm{ml}$ ke dalam cawan Petri dan ditunggu sampai membeku. Penuangan volume $10 \mathrm{ml}$ dilakukan melalui uji coba menggunakan cawan Petri berukuran sama dan diukur dari ketebalan PDA pada cawan Petri.

Isolat patogen Foc diambil dari biakan murni menggunakan cork borer berukuran diameter $5 \mathrm{~mm}$ lalu diletakkan di tengah cawan Petri. Cawan Petri kemudian ditutup rapat menggunakan cling wrap. Kegiatan dilakukan secara aseptik di dalam laminar air flow (LAF). Cawan Petri perlakuan kemudian diinkubasikan dalam suhu ruang untuk diamati pertumbuhan koloninya.

Pengamatan dilakukan terhadap pertumbuhan koloni jamur sampai perlakuan kontrol (tanpa perlakuan esktrak) telah memenuhi cawan Petri. Penghitungan persentase penghambatan menggunakan rumus sebagai berikut:

$$
\mathrm{I}=\frac{(C-T)}{C} \times 100 \%
$$

$\mathrm{I}=$ Persen Penghambatan (\%)

$\mathrm{C}=$ Diameter koloni pada kontrol $(\mathrm{cm})$

$\mathrm{T}=$ Diameter koloni yang diberi perlakuan $(\mathrm{cm})$

\section{Uji Daya Hambat terhadap Produksi Konidia}

Penghitungan kerapatan konidia dilakukan pada jamur 7 hari setelah perlakuan. Sebanyak 1 potong isolat jamur dengan ukuran $5 \mathrm{~mm}$ dari masing-masing ulangan Petri tiap perlakuan diambil lalu dimasukkan ke dalam tabung reaksi berisi $10 \mathrm{ml}$ air. Tabung reaksi divortex selama 3 menit untuk melepaskan konidia. Jumlah konidia dihitung untuk mengetahui kerapatan konidia menggunakan mikropipet lalu diteteskan pada slide haemocytometer dan diamati menggunakan mikroskop (Rosanti dkk., 2014).

Penghitungan produksi konidia Foc dilakukan dengan menghitung jumlah konidia yang terdapat pada 5 kotak sampel haemocytometer. Penghitungan kerapatan konidia menggunakan rumus sebagai berikut (Kiraly, 1974):

$$
\frac{\mathrm{X}(4000)(1000)}{80} \text { atau } 50.000 \mathrm{X}
$$

$\mathrm{X}=$ Jumlah konidia yang dihitung

\section{Uji Daya Hambat terhadap Perkecambahan Konidia Foc}

Uji perkecambahan konidia Foc dilaksanakan seperti yang dilakukan oleh Widhayasa dkk. (2014). Biakan murni jamur Foc berumur 10 hari diambil sebanyak 5 potong dengan ukuran diameter $5 \mathrm{~mm}$, lalu dimasukan ke dalam tabung reaksi yang berisi $5 \mathrm{ml}$ masing-masing ekstrak metanol bunga dan daun kembang telang dengan masing-masing konsentrasi. Untuk perlakuan kontrol, ditambahkan hanya akuades steril. Suspensi di dalam tabung reaksi divortex selama 3 menit untuk melepaskan konidia jamur. Sebanyak $1 \mathrm{ml}$ suspensi diambil menggunakan mikropipet lalu diteteskan di atas gelas arloji. Gelas arloji diinkubasi dalam boks steril yang diberi tisu lembab.

Pengamatan dilakukan pada 24 jam setelah inkubasi menggunakan mikroskop pada perbesaran 400x. Pengamatan dilakukan dengan menghitung jumlah konidia yang berkecambah. Konidia dikatakan berkecambah apabila telah terbentuk tabung kecambah yang panjangnya setengah dari diameter konidia (Steinkellner et al., 2005). 
Persentase perkecambahan konidia dihitung dengan menggunakan rumus sebagai berikut:

$$
K=\frac{\Sigma \text { kontrol }-\Sigma \text { perlakuan }}{\Sigma \text { kontrol }} \times 100 \%
$$

$\mathrm{K} \quad=$ persentase perkecambahan

$\Sigma$ kontrol $=$ jumlah spora yang berkecambah pada kontrol

$\Sigma$ perlakuan $=$ jumlah spora yang berkecambah pada setiap perlakuan

\section{Analisis Data}

Data yang diperoleh dari hasil percobaan dianalisis dengan analisis sidik ragam (ANOVA) menggunakan program SPSS versi 25.0. Jika terdapat pengaruh perlakuan maka dilakukan uji lanjut dengan Uji Jarak Berganda Duncan pada taraf nyata $5 \%$.

\section{HASIL DAN PEMBAHASAN}

Penghambatan Ekstrak Metanol Bunga Kembang Telang terhadap Pertumbuhan Jamur Foc

\section{Penghambatan terhadap Pertumbuhan Koloni}

Ekstrak metanol bunga kembang telang

pada berbagai konsentrasi memberikan nilai penghambatan yang berbeda terhadap pertumbuhan koloni jamur Foc seperti terlihat pada Tabel 1. Penghambatan masing-masing konsentrasi ekstrak berbeda nyata secara uji statistik dibandingkan dengan perlakuan kontrol. Persentasi penghambatan tertinggi diperlihatkan oleh perlakuan konsentrasi $1,8 \%$ (penghambatan 35,11\%), sedangkan penghambatan terendah diperlihatkan oleh perlakuan konsentrasi $0,6 \%$ (penghambatan 20,95\%).

Tabel 1. Penghambatan ekstrak metanol bunga kembang telang terhadap pertumbuhan koloni Foc pada berbagai konsentrasi.

\begin{tabular}{|c|c|c|}
\hline Perlakuan & $\begin{array}{c}\text { Rata-rata } \\
\text { Diameter } \\
\text { Koloni }(\mathrm{cm})\end{array}$ & $\begin{array}{c}\text { Penghambatan } \\
(\%)\end{array}$ \\
\hline Kontrol & $9,00 \mathrm{~d}$ & 0,00 \\
\hline $0,6 \%$ & $7,11 \mathrm{c}$ & 20,95 \\
\hline $1,2 \%$ & $6,09 \mathrm{~b}$ & 32,38 \\
\hline $1,8 \%$ & $5,84 \mathrm{a}$ & 35,11 \\
\hline
\end{tabular}

Mori et al. (1997) mengelompokkan Antifungal Activity (AFA) ekstrak tanaman menjadi 5 kelompok, yaitu AFA $\geq 75 \%$ (sangat kuat); $75 \% \leq \mathrm{AFA}<50 \%$ (kuat); $50 \% \leq \mathrm{AFA}<25 \% \quad$ (sedang); $25 \% \leq \mathrm{AFA}<0 \quad$ (lemah); dan $0 \%$ (tidak aktif). Berdasarkan data tersebut di atas, kemampuan penghambatan ekstrak pada konsentrasi 0,6\% masih tergolong rendah, sedangkan pada konsentrasi 1,2\% dan $1,8 \%$ sudah masuk dalam kategori sedang.

Secara makroskopis, warna miselium jamur Foc semakin memudar seiring dengan pertambahan konsentrasi ekstrak. Pada konsentrasi ekstrak 0,6\% warna hifa sudah mulai terlihat perubahan menjadi agak kekuningan dan semakin putih pada konsentrasi 1,8\%. Pinggiran koloni Foc pada konsentrasi $1,8 \%$ tidak beraturan, miselium tebal dan menumpuk, dan berwarna putih kekuningan (Gambar 1). Pada pengamatan secara mikroskopis, hifa jamur yang diberi perlakuan ekstrak metanol bunga kembang telang mengalami penyusutan, dan banyak membentuk klamidospora dibanding kontrol. Klamidospora pada jamur Fusarium merupakan struktur pertahanan diri yang dibentuk saat Fusarium menghadapi lingkungan yang kurang menguntungkan (Bennett, 2012). Adanya pembentukan klamidospora pada medium yang diberi ekstrak kembang telang menunjukkan bahwa esktrak kembang telang menciptakan kondisi yang tidak kondusif bagi pertumbuhan dan perkembangan jamur Fusarium.

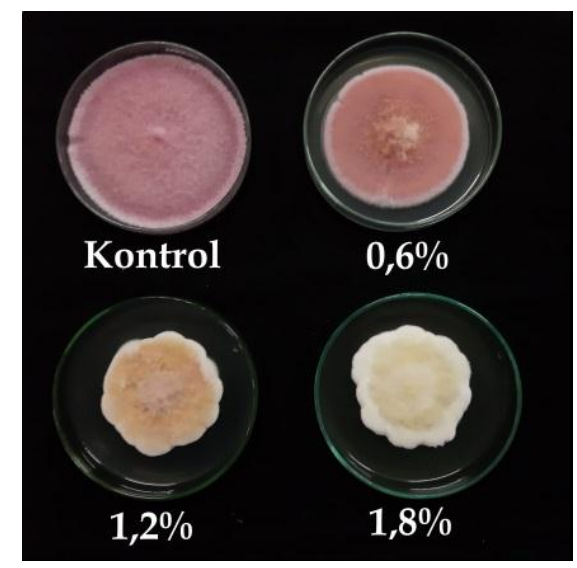

Gambar 1. Pertumbuhan jamur Foc pada berbagai konsentrasi ekstrak metanol bunga Kembang Telang

Koloni jamur Foc semakin terhambat pertumbuhannya seiring dengan meningkatnya konsentrasi uji ekstrak. Perlakuan dengan konsentrasi ekstrak yang meningkat diduga memiliki kandungan senyawa antijamur yang semakin tinggi sehingga menghasilkan nilai 
penghambatan yang semakin tinggi juga. Berdasarkan skrining kandungan metabolit sekunder yang terdapat dalam bunga kembang telang, senyawa yang berpotensi sebagai antijamur di antaranya phlobatannin, flavonoid, dan terpenoid (Darsini \& Shamshad, 2013).

\section{Penghambatan terhadap Produksi Konidia Foc}

Ekstrak metanol bunga kembang telang selain menghambat pertumbuhan koloni jamur juga mampu menurunkan jumlah konidia yang dihasilkan seperti pada Tabel 2. Perlakuan konsentrasi $1,2 \%$ memberikan penghambatan terbaik dan mampu menurunkan jumlah konidia menjadi 7,15 x $10^{4}$ konidia/ml. Angka ini tidak berbeda nyata dengan perlakuan ekstrak 1,8\% (5,00 x $10^{4}$ konidia/ml). Semua perlakuan konsentrasi ekstrak berpengaruh secara nyata dalam uji statistik terhadap perlakuan kontrol.

Tabel 2. Kerapatan konidia jamur Foc pada perlakuan ekstrak metanol bunga Kembang Telang berbagai konsentrasi

\begin{tabular}{lc}
\hline Perlakuan & Jumlah konidia/ml \\
\hline Kontrol & $69,3 \times 10^{4} \mathrm{c}$ \\
$0,6 \%$ & $19,3 \times 10^{4} \mathrm{~b}$ \\
$1,2 \%$ & $7,15 \times 10^{4} \mathrm{a}$ \\
$1,8 \%$ & $5,00 \times 10^{4} \mathrm{a}$ \\
\hline Keterangan: & Angka dalam satu kolom yang dikuti dengan \\
& huruf yang sama menunjukkan tidak berbeda \\
& nyata berdasarkan Uji Jarak Berganda Duncan 5\%.
\end{tabular}

Penurunan produksi konidia pada jamur yang diberi ekstrak metanol bunga kembang telang menunjukkan bahwa adanya gangguan pada metabolisme jamur. Terganggunya metabolisme jamur dapat disebabkan oleh kandungan metabolit sekunder dari bunga kembang telang yang bersifat antijamur. Penurunan konidia pada jamur Foc juga dapat membuat sumber inokulum jamur menjadi berkurang. Foc merupakan jamur monosiklik dimana jumlah inokulum awal menjadi faktor utama laju perkembangan penyakit. Sebagaimana dilaporkan oleh Riska dkk. (2012), semakin tinggi jumlah inokulum jamur Fusarium, maka perkembangan penyakit semakin cepat serta tingkat intensitas penyakit semakin tinggi.

\section{Penghambatan terhadap Perkecambahan Konidia Foc}

Hasil pengujian menggunakan ekstrak metanol bunga kembang telang untuk menghambat perkecambahan konidia Foc dapat dilihat pada Tabel
3. Perkecambahan konidia sangat tinggi pada setiap perlakuan ekstrak. Pada perlakuan konsentrasi ekstrak 0,6\% perkecambahan mencapai 90,92\%, sedangkan pada perlakuan 1,2\% dan 1,8\% justru menstimulasi seluruh konidia untuk berkecambah (100\%).

Hal ini disebabkan oleh karena saat ekstraksi bukan hanya senyawa senyawa yang bersifat antijamur saja yang larut, akan tetapi senyawa lain seperti karbohidrat/gula juga larut. Karbohidrat (gula) diduga mampu menstimulasi munculnya tabung kecambah jamur Foc. Sebagaimana dilaporkan Wang et al. (2007), penambahan gula (glukosa dan sukrosa) dari akar mentimun mampu menstimulasi perkecambahan spora $F$. oxysporum. Peningkatan perkecambahan konidia Foc pada konsentrasi yang semakin meningkat diduga disebabkan oleh akumulasi senyawa karbohidrat yang semakin banyak.

Tabel 3. Perkecambahan konidia Foc pada perlakuan ekstrak metanol bunga kembang telang setelah 24 jam inkubasi

\begin{tabular}{lcc}
\hline Perlakuan & $\begin{array}{c}\text { Rata-rata } \\
\text { Perkecambahan } \\
\text { Konidia (\%) }\end{array}$ & $\begin{array}{c}\text { Penghambatan } \\
(\%)\end{array}$ \\
\hline Kontrol & 65,87 & - \\
$0,6 \%$ & 90,92 & Tm \\
$1,2 \%$ & 100,00 & Tm \\
$1,8 \%$ & 100,00 & Tm \\
\hline
\end{tabular}

Keterangan : $\mathrm{Tm}$ = Tidak menghambat

\section{Penghambatan Ekstrak Metanol Daun Kembang Telang terhadap Pertumbuhan Jamur Foc}

\section{Penghambatan terhadap Pertumbuhan Koloni Foc}

Persentase penghambatan jamur Foc oleh ekstrak metanol daun Kembang Telang dapat dilihat pada Tabel 4. Perlakuan ekstrak dengan konsentrasi 2,4\% mampu menghasilkan nilai penghambatan tertinggi yaitu sebesar $47,11 \%$ sedangkan penghambatan terendah terdapat pada perlakuan konsentrasi 0,8\% dengan persentasi sebesar 29,33\%. Setiap konsentrasi ekstrak memiliki kemampuan penghambatan yang sedang berdasarkan kategori Mori et al. (2007). dan berpengaruh nyata secara uji statistik apabila dibandingkan dengan perlakuan kontrol.

Kerusakan hifa jamur Foc oleh ekstrak metanol daun Kembang Telang juga diamati melalui bantuan mikroskop. Jarak antar sekat pada hifa 
perlakuan lebih sempit, hifa mengerut dan cenderung membentuk klamidospora dibanding kontrol. Koloni jamur Foc yang tidak diberi perlakuan memiliki warna merah muda dengan pertumbuhan merata pada pinggir koloni, serta permukaan yang cenderung rata.

Tabel 4. Penghambatan ekstrak metanol daun Kembang Telang terhadap pertumbuhan koloni Foc pada berbagai konsentrasi

\begin{tabular}{lcc}
\hline Perlakuan & $\begin{array}{c}\text { Rata-rata } \\
\text { Diameter Koloni } \\
(\mathrm{cm})\end{array}$ & $\begin{array}{c}\text { Penghambatan } \\
(\%)\end{array}$ \\
\hline Kontrol & $9,00 \mathrm{~d}$ & 0,00 \\
$0,8 \%$ & $6,36 \mathrm{c}$ & 29,33 \\
$1,6 \%$ & $5,22 \mathrm{~b}$ & 42,00 \\
$2,4 \%$ & $4,76 \mathrm{a}$ & 47,11
\end{tabular}

Keterangan: Angka dalam satu kolom yang diikuti dengan huruf yang sama menunjukkan data tidak berbeda nyata berdasarkan Uji Jarak Berganda Duncan 5\%

Koloni jamur Foc yang diberi perlakuan semakin menguning dengan pertambahan konsentrasi ekstrak. Selain itu pinggiran koloni tidak beraturan, permukaan tidak beraturan dan miselium lebih tipis dibanding kontrol (Gambar 2).

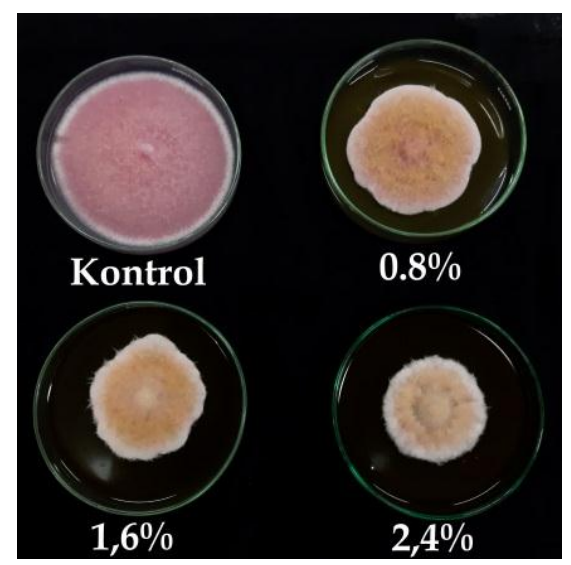

Gambar 2. Pertumbuhan jamur Foc pada berbagai konsentrasi ekstrak metanol daun Kembang Telang

Kerusakan pada hifa jamur seperti yang terjadi pada jamur Foc juga dilaporkan oleh Kamilla et al. (2009) pada pengujian ekstrak metanol daun kembang telang terhadap $A$. niger. Hifa jamur $A$. niger kehilangan sitoplasma dan diameter dinding hifa menjadi lebih tipis, terdistorsi, dan terjadi gangguan pada dinding sel. Hasil uji fitokimia yang dilakukan oleh Kamilla et al. (2009) menunjukkan bahwa daun kembang telang memiliki kandungan metabolit sekunder seperti tanin, cardiac glycosides, steroid dan alkaloid. Senyawa-senyawa tersebut diketahui memiliki sifat antijamur (Negri at al., 2014).

\section{Penghambatan terhadap Produksi Konidia Foc}

Pemberian ekstrak metanol kembang telang ternyata mampu menurunkan produksi konidia Foc pada pengujian secara in-vitro seperti pada Tabel 5 . Jumlah konidia yang terendah terdapat pada perlakuan konsentrasi 2,4\% sebesar 1,45 x $10^{4}$ konidia/ml dan jumlah konidia tertinggi terdapat pada perlakuan konsentrasi 1,6\% sebesar 5,70 x $10^{4}$ konidia/ml. Meskipun demikian, masing-masing perlakuan konsentrasi $0,8 \%$; $1,6 \%$; dan $2,4 \%$ tidak memberikan hasil yang berbeda nyata secara uji statistik namun berbeda nyata apabila dibandingkan dengan perlakuan kontrol.

Tabel 5. Kerapatan konidia jamur Foc pada perlakuan ekstrak metanol daun kembang telang berbagai konsentrasi

\begin{tabular}{lc}
\hline Perlakuan & Jumlah konidia/ml \\
\hline Kontrol & $67,9 \times 10^{4} \mathrm{~b}$ \\
$0,8 \%$ & $3,55 \times 10^{4} \mathrm{a}$ \\
$1,6 \%$ & $5,70 \times 10^{4} \mathrm{a}$ \\
$2,4 \%$ & $1,45 \times 10^{4} \mathrm{a}$
\end{tabular}

Keterangan: Angka dalam satu kolom yang diikuti dengan huruf yang sama menunjukkan data tidak berbeda nyata berdasarkan Uji Jarak Berganda Duncan 5\%

Berdasarkan data produksi konidia Foc, perlakuan konsentrasi ekstrak metanol daun 1,6\% menghasilkan jumlah konidia yang lebih banyak apabila dibandingkan dengan perlakuan konsentrasi lainnya. Hal ini mungkin disebabkan oleh karena pada perlakuan ekstrak 2,4\% terjadi malformasi hifa yang lebih banyak dibanding pada konsentrasi 1,6\%. Kerusakan hifa ini membuat kemampuan jamur dalam memproduksi konidia menjadi terhambat. Kerusakan hifa ini dapat dilihat secara makroskopis pertumbuhan koloni Foc pada konsentrasi 2,4\% yang miseliumnya lebih tipis, sedangkan pada konsentrasi $1,6 \%$ miselium lebih menumpuk. Meskipun demikian, secara statistik semua perlakuan ekstrak metanol daun Kembang Telang memiliki pengaruh yang sama.

\section{Penghambatan terhadap Perkecambahan Konidia Foc}


Ekstrak metanol daun Kembang Telang tidak mampu menghambat perkecambahan konidia Foc seperti pada Tabel 6. Pada perlakuan ekstrak metanol daun $0,8 \%$ perkecambahan konidia mencapai $81,43 \%$, tetapi belum menghambat perkecambahan konidia apabila dibandingkan dengan perlakuan kontrol. Angka ini lebih rendah bila dibandingkan dengan perlakuan ekstrak 1,6\% dan 2,4\% yang justru menstimulasi perkecambahan konidia Foc sampai $100 \%$.

Tabel 6. Perkecambahan konidia Foc pada perlakuan ekstrak metanol daun kembang telang setelah 24 jam inkubasi

\begin{tabular}{lcc}
\hline Perlakuan & $\begin{array}{l}\text { Rata-rata } \\
\text { Perkecambahan } \\
\text { Konidia (\%) }\end{array}$ & $\begin{array}{c}\text { Penghambatan } \\
(\%)\end{array}$ \\
\hline Kontrol & 70,71 & - \\
$0,8 \%$ & 81,43 & Tm \\
$1,6 \%$ & 100,00 & Tm \\
$2,4 \%$ & 100,00 & Tm \\
\hline
\end{tabular}

Keterangan: $\mathrm{Tm}=$ Tidak menghambat

Konidia jamur yang berkecambah menunjukkan bahwa ekstrak metanol daun kembang telang juga mengandung senyawa yang dapat mendukung perkecambahan konidia. Pembentukan tabung kecambah pada konidia ini diduga terjadi karena adanya adanya kandungan karbohirat (gula). Hal ini sejalan dengan studi skrining kandungan fitokimia yang dilakukan oleh Chauhan et al., (2012) yang menyatakan bahwa daun kembang telang memiliki kandungan gula.

Kemampuan karbohidrat/gula dalam menstimulasi perkecambahan konidia sudah banyak dilaporkan (Wang et al., 2007; Golan, 2001). Adanya karbohidrat/gula yang ikut terlarut dapat disebabkan oleh penggunaan pelarut organik yang digunakan. Penggunaan metanol dilaporkan dapat melarutkan berbagai jenis gula seperti glukosa, fruktosa, laktosa, dll. (Montanes et al., 2007). Meskipun demikian, senyawa-senyawa dalam daun kembang telang yang dapat menstimulasi perkecambahan konidia jamur masih perlu diteliti lebih lanjut.

\section{SIMPULAN}

Berdasarkan pengujian yang telah dilakukan, ekstrak tanaman kembang telang memiliki potensi yang baik dalam menghambat pertumbuhan hifa dan produksi konidia jamur Foc, akan tetapi tidak mampu menghambat perkecambahan konidia jamur Foc. Ekstrak metanol bunga kembang telang pada konsentrasi 1,8\% memberikan penghambatan tertinggi yaitu sebesar $35,11 \%$, sedangkan pengambatan tertinggi oleh ekstrak metanol daun kembang telang terjadi pada konsentrasi 2,4\%, yaitu sebesar 47,11\%. Kerapatan konidia terendah jamur terdapat pada perlakuan ekstrak metanol bunga pada konsentrasi 1,2\% sejumlah 7,5 x $10^{4} \mathrm{konidia} / \mathrm{ml}$ dan pada ekstrak metanol daun pada konsentrasi $0,8 \%$ sejumlah $3,55 \mathrm{x}$ $10^{4} \mathrm{konidia} / \mathrm{ml}$.

\section{DAFTAR PUSTAKA}

Agrios, GN. 2005. Plant Pathology. $5^{\text {th }}$ Edn. Elsevier Academic Press, New York. USA.

Badan Penelitian dan Pengembangan Pertanian. 2007. Prospek dan Arah Pengembangan Agribisnis Bawang Merah. Edisi Kedua. Departemen Pertanian.

Badan Penelitian dan Pengembangan Pertanian. 2012. Pestisida Nabati. Pusat Penelitian dan Pengembangan Perkebunan, Bogor.

Badan Pusat Statistik. 2019. Produksi Tanaman Sayuran: Bawang Merah. Tersedia secara online: www.bps.go.id (diakses 27 Januari 2019).

Bennett, RS. 2012. Survival of Fusarium oxysporum f. sp. vasinfectum chlamydospores under solarization temperatures. Plant Dis. 96:15641568.

Chauhan, N, S Rajvaidhya and BK Dubey. 2012. Pharmacognostical, phytochemical and pharmacological review on Clitoria ternatea for antiasthmatic activity. IJPSR. 3(2):398404.

Chethana, BS, G Ganeshan, AS Rao, and K Bellishree. 2012. In vitro evaluation of plant extracts, bioagents and fungicides against Alternaria porri (Ellis) Cif., causing purple blotch disease of onion. Pest Management in Horticultural Ecosystems. 18(2):194-198.

Darsini, IP and S Shamshad. 2013. Antimicrobial activity and phytochemical evaluation of Clitoria ternatea. IJSR. 6(14):283-285.

Das, N, A Ghosh, and P Chatterjee. 2014. Antifungal effect of Clitoria ternatea L. leaf extract on seeds of Pisum sativum L. in relation to some biochemical parameters. International Journal of Research in Ayurveda and Pharmacy. 5(4):536-539.

Dinakaran, D, G Gajendran, S Mohankumar, G Karthikeyan, S Thiruvudainambi, EI 
Jonathan, R Samiyappan, DG Pfeiffer, EG Rajotte, GW Norton, S Miller, and R Muniappan. 2004. Evaluation of integrated pest and disease management module for shallots in Tamil Nadu, India: a farmer's participatory approach. Journal of Intergrated Pest Management. 4(2):1-9.

Dono, D, S Hidayat, C Nasahi, dan E Anggraini. 2008. Pengaruh ekstrak biji Barringtonia asiatica L. (Kurz) (Lecythidaceae) terhadap mortalitas larva dan fekunditas Crocidolomia pavonana F. (Lepidoptera: Pyralidae). Jurnal Agrikultura. 19(1):5-14.

Golan, RB. 2001. Postharvest Diseases of Fruits and Vegetables. Elsevier Academic Press, New York. USA.

Kamilla, L, SM Mnsor, S Ramanathan, and S Sasidharan. 2009. Effects of Clitoria ternatea leaf extract on growth and morphogenesis of Aspergillus niger. Microsc. Microanal. 15:366-372.

Kiraly, Z. 1974. Methods in Plant Pathology. Elsevier Scientific Publishing Co. New York. 279-280.

Kurniasih, R, S Djauhari, A Muhibuddin, dan EP Utomo. 2014. Pengaruh sitronelal serai wangi (Cymbopogon winterianus Linn) terhadap penekanan serangan Colletotrichum sp. pada tanaman bawang daun (Allium fistulosum L.). Jurnal HPT. 2(4):11-21.

McDonald, M, MA Jaime, and MHY Hovius. 2004. Management of diseases of onions and garlic. Diseases of Fruits and Vegetables. 2:149-200.

Montanes, F, A Olano, E Ibanez, and T Fornari. 2007. Modeling solubilities of sugars in alcohols based on original experimental data. AIChE Journal. 53(9):2411-2418.

Mori, M, M Aoyama, S Doi, A Kanetoshi and T Hayashi. 1997. Antifungal activity of bark extract of deciduous trees. Holz als Roh und Werkstoff. 55:130-132.
Naz, S, SQN Batool, and N Munir. 2013. Antifungal activity of Clitoria ternatea L. extracts against different fungal species. Mycopath. 11(2):9194.

Negri, M, TP Salci, CS Shinobu-Mesquita, IRG Capoci, TIE Svidzinski, and ES Kioshima. 2014. Early state research on antifungal natural products. Molecules. 19:2925-2956.

Riska, Jumjunidang, dan C Hermanto. 2012. Hubungan antara tingkat konsentrasi inokulum Fusarium oxysporum f. sp. cubense VCG 01213/16 dengan perkembangan penyakit layu pada kultivar pisang rentan. J Hort. 22(2):155-163.

Rosanti, KT, IR Sastrahidayat, AL Abadi. 2014. Pengaruh jenis air terhadap perkecambahan spora jamur Colletotrichum capsici pada cabai dan Fusarium oxysporum pada tomat. Jurnal HPT. 2(3):109-120.

Steinkellner, S, R Mammerler, and $\mathrm{H}$ Vierheilig. 2005. Microconidia germination of the tomato pathogen Fusarium oxysporum in the presence of root exudates. Journal of Plant Interactions. 1(1):23-30.

Suganda, T, dan SR Adhi. 2017. Uji pendahuluan efek fungisida bunga Kembang Telang (Clitoria ternatea L.) terhadap jamur Fusarium oxysporum f.sp. cepae penyebab penyakit moler pada bawang merah. Jurnal Agrikultura. 28(3):136-140.

Susanti, AD. 2018. Evaluasi Aplikasi Pestisida pada Pertanaman Bawang Merah di Kabupaten Brebes. Bogor : Institut Pertanian Bogor.

Wang, X, F Wu, and X Han. 2007. Effects of sugars on germination and mycelium growth of Fusarium Oxysporum. Allelopathy Journal. 20(2):339-346.

Widhayasa, B, IR Sastrahidayat, dan S Djauhari. 2014. Perkecambahan jamur Alternaria solani dan infeksinya pada sembilan varietas tomat. Jurnal Hama Penyakit Tumbuhan. 2(3):102108. 